\title{
KONSEP HAK MILIK DALAM EKONOMI ISLAM
}

\author{
AN Ras Try Astuti, Andi Faisal \\ anrastryastuti@stainparepare.ac.id \\ hadi.mortheza@gmail.com
}

\begin{abstract}
Capitalism as an economic system that is implemented by most countries in the world today, in fact it gave birth to injustice and social inequality are increasingly out of control. Social and economic inequalities are felt both between countries (developed and developing countries) as well as in society itself (the rich minority and the poor majority). The condition is born from the practice of departing from faulty assumptions about the man. In capitalism the individual to own property released uncontrollably, causing a social imbalance. On the other hand, Islam never given a state model that guarantees fair distribution of ownership for all members of society, ie at the time of the Prophet Muhammad established the Islamic government in Medina. In Islam, the private ownership of property was also recognized but not absolute like capitalism. Islam also recognizes the forms of joint ownership for the benefit of society and acknowledges the ownership of the state that aims to create a balance and social justice.
\end{abstract}

Keywords: Capitalism, Islam, Economics, Ownership and Distribution.

\section{A. LATAR BELAKANG}

Rasa ingin memiliki adalah faktor utama yang mendorong seseorang untuk melakukan sesuatu. Rasa ini memberikan motivasi sekaligus tujuan kepada manusia. Rasa ingin memiliki meliputi seluruh dimensi kehidupan manusia dari hal yang material seperti kepemilikan harta benda sampai kepada hal yang abstrak seperti ingin memiliki kekuasaan/jabatan dan pangkat bahkan hal yang bersifat spiritual sekalipun seperti ingin memiliki kebahagiaan. Dalam ilmu ekonomi, rasa ingin memiliki ini sepadan dengan konsep kebutuhan. Dengan kata lain, manusia ingin memiliki sesuatu karena membutuhkan sesuatu tersebut.

Ekonomi pada dasarnya hadir untuk mengatur mengenai kepemilikan yaitu kepemilikan properti. Aristoteles mengatakan untuk hidup baik manusia membutuhkan properti. Baik individu maupun negara membutuhkan properti untuk mencapai tujuannya, yaitu tujuan yang baik. Lebih lanjut aristoteles menjelaskan bahwa "property is a part of household, and the artof acquiring the propertyis a part of the 
art of managing the household". Properti adalah bagian dari rumah tangga dan cara mengumpulkan properti adalah bagian dari cara mengatur rumah tangga. Disini aristoteles memberikan penjelasan bahwa properti adalah sesuatu yang tidak dapat dipisahkan dari pengelolaan rumah tangga. Kemudian aristoteles menekankan bahwa "no man can live well, or indeed live at all, unless he be provided with necessary. Orang tidak dapat hidup dengan baik bahkan hidup seadanya tanpa menyediakan properti yang dibutuhkannya. Disini aristoteles menekankan kepada penekanan hidup yang baik dan menjadikan properti sebagai syarat seseorang untuk hidup dengan baik, oleh karena itu dibutuhkan pengaturan khusus terhadap kepemilikan properti dan cara mendapatkannya. Pengaturan terhadap properti bertujuan agar properti digunakan sesuai dengan tujuannya (oikonomia) dan untuk menghindari terjadinya konflik sosial yang diakibatkan oleh hasrat manusia untuk memiliki. ${ }^{1}$

Penjelasan aristoteles diatas menjadi fondasi sistem ekonomi kapitalisme.Dalamkapitalismesendiri ada dua pertanyaan utama terkait konsep hak milik, yaitu bagaimana cara mendapatkan sesuatu dan apabila telah mendapatkan sesuatu, apa yang bisa dilakukan terhadap

${ }^{1} \mathrm{M}$ Anton Athoillah \& Bambang Q Aness, Filsafat Ekonomi Islam, 2005 sesuatu tersebut. Contoh sederhana dalam kepemilikian suatu buku, ada dua cara untuk mendapatkan suatu buku yaitu dengan cara membeli dan dengan cara diberi oleh orang lain. Diluar kedua cara ini maka kepemilikan terhadap buku menjadi tidak sah atau illegal misalnya dengan mencuri. Selanjutnya, setelah buku diperoleh buku tersebut bisa digunakan untuk menambah informasi, dijadikan bungkus kacang atau dijadikan pengalas meja. Dari berbagai alternatife, baik cara mendapatkan buku maupun digunakan untuk apa, tentu saja kita akan mengikuti apa yang menjadi norma sosial yang berlaku dalam kehidupan bermasyarakat yaitu membeli atau diberikan oleh orang lain secara sah maupun digunakan untuk menambah informasi. Hal ini sesuai dengan apa yang dijelaskan oleh aristoteles bahwa segala sesuatu harus mengacu pada tujuan dasar sesuatu tersebut. ${ }^{2}$

Akantetapi, konsepinikemudian terbukti memiliki kelemahan mendasar yaitu terkait pertanyaan siapa memiliki apa, bagaimana, jumlah seperti apa dan untuk tujuan apa?. Sebelum menjawab pertanyaan ini ada baiknya kalau kita kembali mendalami pandangan aristoteles mengenai penggolongan hak milik properti. Aristoteles menggolongkan

${ }^{2}$ Save M Dagun Pengantar filsafat ekonomi, Penerbit Rineka Cipta, 1992 
properti dalam tiga golongan, yaitu properti dasar adalah properti yang dibutuhkan oleh manusia untuk hidup dan bertahan hidup. Yaitu tubuh manusia dan segala unsur yang terkait dengan tubuh manusia seperti energi,waktu dan kemampuan fisiknya. Kemudian properti kedua adalah properti diluar diri manusia seperti udara, air bumi dan seluruh isinya. Kemudian properti ketiga adalah seluruh hasil olahan manusia seperti peralatan, kendaraaan, rumah dan lainnya. ${ }^{3}$

Terkait pertanyaan pertama, siapa memiliki apa. Kapitalisme memandang bahwa manusia dapat memiliki ketiga golongan properti yang disebut diatas. Mulai dari kepemilikan atas diri sendiri sampai dengan kepemilikan atas peralatan. Dari konsep ini, perbudakan diganti dengan konsep tenaga kerja (labour/ employee) yang mana dengan konsep ini seseorang yang bekerja pada orang lain diberikan sejumlah uang atau sesuatu yang bernilai sebagai pengganti atas kekuatan fisik, energi dan waktu yang diberikan kepada orang tersebut. ${ }^{4}$ Manusia juga bisa memiliki tanah dan kekayaan baik yang ada diatas maupun didalamnya. Akantetapi,konsepinimembernarkan

${ }^{3} \mathrm{M}$ Anton Athoillah \& Bambang Q Aness, Filsafat Ekonomi Islam, 2005

${ }^{4}$ Mark Skousen, Sang Maestro "Teori

- Teori Ekonomi Modern": Sejarah Pemikiran Ekonomi, alih bahasa Tri Wibowo Budi Santoso, Prenada, 2006. adanya praktek eksploitasi baik eksploitasi terhadap manusia maupun eksploitasi terhadap alam dan isinya. Eksploitasi yang berlibahan melahirkan anomali sosial dimana manusia berubah menjadi mesin pekerja dan juga kerusakan alam akibat eksploitasi yang berlebihan.

Pertanyaan kedua terkait bagaimana mendapatkan sesuatu, kapitalisme memandang bahwa setiap orang bisa menggunakan berbagai cara (sepanjang sesuai dengan hukum yang berlaku) untuk mendapatkan properti. Bahkan, kapitalisme mendesain mekanisme kompetisiagar setiap orang dapat menemukan cara baru untuk mendapatkan sesuatu. Asumsi ini berimplikasi pada lahirnya dominasi dan monopoli terhadap suatu sumberdaya. Orang-orangyang diuntungkan karena memiliki status sosial yang lebih tinggi dari orang lain, serta akses terhadap kekuasaan sangat memudahkan dirinya untuk memperoleh sesuatu dibandingkan dengan orang lain. Sumber daya yang langka kemudian menjadi faktor utama lahirnya ketidakadilan dan ketimpangan sosial ekonomi akibat adanya distribusi sumber daya yang tidak berkeadilan. ${ }^{5}$

Pertanyaan ketiga yang terkait dengan jumlah, kapitalisme memandang bahwa setiap orang tidak dibatasi untuk memiliki sesuatu

${ }^{5}$ Mubyarto, Membangun Sistem Ekonomi, BPFE Yogyakarta, 2000 
dalam jumlah yang tidak terbatas. Konsekuensi dari konsep ini adalah lahirnya ekonomi hasrat, yaitu ekonomi yang mengekploitasi hasrat manusia untuk mengkunsumsi secara terus menerus terhadap sesuatu yang secara real tidak dibutuhkannya. Setiap orang "dipaksa" untuk terus mengkunsumsi dengan menampilkan berbagai citra terhadap suatu produk. Citra laki - laki sejati untuk produk rokok, citra kelas atas untuk produk mobil. Berbagai citra ini ditampilkan untuk menggesar hasrta manusia untuk mengkonsumsi berdasrkan kebutuhan menjadi mengkonsumsi berdasrkan citra yang dilekatkan terhadap produk tersebut. ${ }^{6}$

Pertanyaan keempat untuk tujuan apa menekankan kepada pemanfaatan suatu properti yang dimiliki berdasarkan tujuan dari properti tersebut (prinsip teleologis dari aristoteles). Namun, oleh kapitalisme tujuan dari memiliki sesuatu tidak lebih dari memuaskan hasrat konsumsi yang tidak terbatas dan tidak terkontrol. Hanya dalam kapitalisme kita biasa melihat orang yang mengoleksi hingga ratusan sepatu dan pakaian, berbagai macam kendaraan dan berderet - deret rumah dan berbagai properti lainnya. Kapitalisme tidak memberikan tujuan transcendental dari kepemilikan

${ }^{6}$ Yasraf Amir Piliang, Dunia Yang Dilipat: Tamasya Melampui Batas - Batas Kebudayaan, Edisi ke tiga, Penerbit Matahari, 2011. properti, tapi kapitalisme menjunjungg tinggi imanensi yang bersifat banal. ${ }^{7}$ Hal inipun menciptakan ketimpangan antara negara kaya dan negara miskin.

Berbagai kelemahan dan penyimpangan yang dengan mudah dapat ditemukan dalam realitas ekonomi saat ini menyiratkan akan pentingnya kajian yang mendalam mengenai sistem ekonomi yang kita pilih atau dipilahkan kepada kita untuk dijalani dalam kehidupan baik individu maupun dalam kehidupan sosial. Pada dasarnya, suatu sistem diciptakanuntukmengaturkehidupan sosial manusia yang berdasarkan atas pandangan dunia atau asumsi tentang manusia, alam dan realitas secara keseluruhan. Oleh karena itu, suatu sistem tidaklah bersifat mutlak tapi sistem bisa diperbaiki dan atau diganti dengan suatu sistem yang secara argumentatif dan rasional lebih baik dalam mengatur kehidupan personal dan sosial manusia menuju kehidupan yang lebih baik.

Agama islam sebagai suatu agama tidak hanya berisi aturan aturan yang terbatas pada kehidupan personal manusia seperti agama agama yang lain. Tapi islam juga dapat menjadi suatu sistem yang mengatur kehidupan sosial dalam suatu negara seperti yang pernah

${ }^{7}$ Yasraf Amir Piliang, Posrealitas: realitas Kebudayaan dalam era posmetafisika, Penerbit Jalasutra, 2009. 
dipraktekkan pada masa rasulullah SAW di kota madinah. ${ }^{8}$ Namun, suatu sistem yang baik adalah sistem yang bersifat dinamis dan fleksibel terhadap perkembangan jaman. Sebagaimana yang dikatakan WF. Hegel bahwa masyarakat senantiasa mengalami perkembangan di setiap zamannya atau dengan kata lain sejarah senantias bergerak. ${ }^{9} \mathrm{Hal}$ ini juga dijelaskan oleh Ibnu Khaldun bahwa perkembangan masyarakat adalah suatu kepastian, sepanjang sejarah senantiasa ada saatu peradaban yang lahir dan hilang. Siklus suatu peradaban sama seperti siklus hidup manusia, ada periode kelahiran, masa remaja, masa dewasa, masa tua hingga kematian. ${ }^{10}$

Islam sebagai suatu agama pernah menjadi peradaban yang mempraktekkan keadilan ekonomi dan sosial yang belum pernah dipraktekkan pada masa sebelumnya. Namun, sangat disayangkan akibat dari orientasi politik yang sangat tinggi, para pemimpin islam semenjak berakhirnya dinasti abbasiyah membawa peradaban islam kearah kemerosotan hingga akhirnya runtuh. ${ }^{11}$ Berakhirnya peradaban islam ini kemudian ditandi dengan

\footnotetext{
${ }^{8}$ Jalaluddin Rahmat, Catatan Kang Jalal, Penerbit Remaja Rosda Karya, 1998.

${ }^{9}$ Bertand Russel "sejarah Filsafat Barat dan impilikasinya terhadap kondisi sosial politik masa kini"

${ }^{10}$ Ibnu Khaldun "Mukadimah"

${ }^{11}$ Murthada Mutahari, Masyarakat dan Sejarah : kritik Islam atas Marxisme dan Teori Lainnya, Penerbit Mizan 1990.
}

kelahiran kembali bangsa eropa yang memperkenalkankonsepbarutentang manusia. Akan tetapi, konsep baru tersebut di kemudian hari ternyata terbukti keliru dan salah dalam mengkonsepkan tentang manusia, hingga akhirnya membawa manusia kearah dekandensi dan kehidupan material hedonis yang belum pernah terjadi sebelumnya. Tidak hanya itu, konsep yang salah ini juga justru membawa ummat manusia ke dalam suatu perang yang sangat mematikan dimana jutaan orang meninggal dan sampai hari ini manusia masih dihantui oleh bayangan horror akan perlombaan senjata yang dapat mengakhiri kehidupan manusia di muka bumi ini. ${ }^{12}$

Melihat kegagalan eropa dalam membangunsuatuperadabanmanusia yang berkeadilan dan bermartabat, berbagaipemikirmuslim dariberbagai disiplin ilmu mencoba menggali kembali konsep - konsep yang ada dalam islam mengani bagaimana harusnya kehidupan manusia diatur. Atau bagaimana membantuk suatu sistem yang dapat menjamin distribusi pendapatan dan sumber daya ekonomi dan sosial secara berkedilan diantara seluruh ummat manusia. ${ }^{13}$ Kelahiran kembali semangat Berislam pun

${ }^{12}$ Jujun S Suriasumantri, Filsafat Ilmu Pengetahuan sebuah pengantar Populer, Penerbit Pustaka Sinar Harapan, 2007.

${ }^{13}$ Muhammad Baqir Sadr Iqtishaduna, Penerbit Zahra Publishing House, 2008. alih bahasa oleh Yudi. 
tidak hanya terbatas bagi kalangan elite (intelektual, akdemisi), tapi juga dikalangan masyarakat khususnya masyarakat menengah dan mahasiswa serta kelompok pemuda.

Dalam artikel ini penulis akan mencoba mengkaji sudut pandang islam terkait dengan konsep hak milik. Sebagaimana yang telah dijelaskan diatas, konsep hak milik merupakan salah satu asumsi dasar yang membangun suatu sistem ekonomi. ${ }^{14}$ Lebih mendalam dari itu, konsep tentang hak milik berangkat dari pandangan atau asumsi tentang manusia, alam dan realitas secara keseluruhan. ${ }^{15}$ Oleh karena itu, dalam artikel ini akan dibagi dalam dua tema pokok yaitu asumsi tentang manusia dalam pandangan filsafat barat dan islam, dan asumsi tentang hak milik dalam pandangan ekonomi kapitalisme, sosialisme dan islam sebagai turunan dari asumsi tentang manusia.

\section{B. PEMBAHASAN}

\section{Hakekat Manusia.}

Pada dasarnya asumsi tentang manusia, alam dan realitas tidak saja menjadi fondasi bangunan sistem ekonomi, akan tetapi juga adalah fondasi dari seluruh bangunan kebudayaan manusia sepanjang sejarah. Manusia menciptakan suatu

\footnotetext{
${ }^{14} \mathrm{ibid}$

${ }^{15} \mathrm{M}$ Anton Athoillah \& Bambang Q Aness, Filsafat Ekonomi Islam, 2005
}

kebudayaan berdasarkan asumsi tersebut serta membangun suatu peradaban diatas kebudayaan.

Diskursusu tentang manusia, alam dan realitas adala suatu diskursus yang dapat dilacak pada penjelasan Plato mengeni alam idea hinga kemudian asumsi tenteng manusia diterima sebagai suatu kebenaran ilmiah dalam era modernism ${ }^{16}$. Namun, dalam beberapa decade terakhir ini, diskursus mengenai topic ini kembali diangkat kepermukaan oleh pemikir posmedern setelah melihat kegagalan modernism dalam membawa manusia menuju cita cita modernism yang dicanagkan oleh para filosof diabad pertengahan. Pun demikian halnya dengan para intelektual muslim yang tampil untuk mengemukakan padangannya tentang manusia berdasarkan tafsiran atas ajaran islam yang bersumber dari alquran dan hadist.

Diskursus tentang modernism dapat dilacak dari pemikiran Rene Descartes $(1596$ - 1650) yang dijuluki sebagaiBapakFilsafatModern.Julukan tersebut diberikan dikarenakan Descartes memberikan suatu metode berpikir yang baru. Gagasan utama Descartes adalah mengenai logika Oposisi Biner. Menurutnya, manusia terdiri dari dua unsure jiwa dan badan. Jiwa berkaitan dengan rasio

${ }^{16} \mathrm{~F}$ Budi Hardiman, Pemikiran-Pemikiran yang Membentuk Dunia Modern, Penerbit Erlangaa, 2011. 
sementara badan berkaitan dengan hasrat bawaan. Jiwa dan badan tidak memiliki kaitan selain bahwa jiwa harus mengendalikan badan agar manusia terhindar dari sifat kebinatangan. Kesadaran manusia akan sesuatu yang bersifat asbtarak seperti gagasan tentang Tuhan, kebaikan, keindahan, merupakan ide bawaan yang sudah ada dalam jiwa/ rasio yang sifatnya inheren. ${ }^{17}$

Filsafat modernism mendapatkan fondasi radikalnya melalui (1711 - 1776) David Hume adalah filosof inggris yang memiliki pandangan materialism. David hume memului filsafatnya dengan melancarkan kritikan sengit terhadap konsep rasionalisme yang diperkenalkan oleh Descartes. Hume menolak dengan tegas gagasan Descartes mengenai subtansi jiwa yang mengetahui gagasan abstrak. Menurut Hume, pengetahuan adalah kumpulan persepsi saja " $a$ bundle of perceptions". Kalau persepsi tersebut dihilangkan, maka kita juga akan kehilangan kesadaran dan diri, seperti pada saat orang sementara tidur, daya persepsinya hilang dan orang tersebut juga kehilangan kesadaran. Adapun mengenai konsep asbtrak, hume mengatakan bahwa konsep tersebut adalah hasil dari imajinasi pikiran dalam melepaskan ciri - ciri partikulernya. ${ }^{18}$

${ }^{17} \mathrm{ibid}$

${ }^{18} \mathrm{ibid}$
Gagasan hume mengenai pengetahuan hanyalah hasil persepsi kemudian melahirkan aliran pemikiranempirisme,yaitupemikiran yang menolak segala bentuk pengetahuan yang tidak berasal dari pengamatan empris. Empirisme ini kemudian menjadi landasan penilitian imliah sains modern melalui aliran positivism logis. ${ }^{19}$ Yaitu aliran yang memperkenalkan metode ilmiah dalam penelitian dan konstruksi ilmu pengetahuan modern. Mashab ini menghilangkan nilai dari ilmu pengetahuan dan hanya menjadikan pengetahuan sebagai instrument yang membantu manusia untuk memenangkan kompetisi dalam hidupnya. Konsep ini juga kemudian melahirkan pengetahuan sebagai alat kekuasan, yaitu pengetahuan yang dikonstruk untuk menguatkan status quo. ${ }^{20}$ Oleh empirisme seperti yang dijelaskan diatas, pengetahuan manusia direduksi menjadi sekedar sensasi dan kesan - kesan empiris, apa yang tidak bersumber dari gagasan empiris hanya dianggap sebagai gagasan yang tidak ilmiah.

Empirisme David Hume sangat mempengaruhi pandagan Adam Smith mengenai ekonomi. ${ }^{21}$

${ }^{19}$ T.M. Soerjanto Poespowardojo \& Alexander Seran, Filsafat Ilmu Pengetahuan, Penerbit Kompas, 2015.

${ }^{20} \mathrm{~F}$ Budi Hardiman, Pemikiran-Pemikiran yang Membentuk Dunia Modern, Penerbit Erlangaa, 2011.

Ibid 
Sebagaimana yang diketahui Adam Smith merupakan perintis sistem ekonomikapitalisme melaluibukunya An inquiry in to the nature of the wealth of nations. Pada dasarnya, gagasan ekonomi adam smith memiliki asumsi - asumsi mendasar yang dapat dilacak dari bukunya yang berjudul The Teori of Moral Sentiment. ${ }^{22}$

Adam smith membangun sistem ekonomi kapitalisme dengan membangun 3 asumsi mengenai kecendrungan manusia. Yaitu:

a. Cinta pada diri sendiri dan simpati kepada orang lain (self love $\&$ Simpathy)

b. Keinginan untuk bebas dan keterikatan pada rasa sopan santun terhadap orang lain (the desire to be free and sense of propriety)

c. Kebiasaan untuk bekerja, menghasilkan apa yang dibutuhkan, dan kecedrungan untuk mengadakan pertukaran hasil produksi sendiri dengan hasil produksi orang lain (the habbit of labour and the propensity to exchange). ${ }^{23}$

Menurut adam smith ketiga kecenderungan manusia tersebut harus diberikan kebebasan untuk berjalan secara alamiah. Dengan begitu, maka proses ekonomi akan

${ }^{22}$ W. I. M. Poli Tonggak - Tonggak Sejarah Pemikiran Ilmu ekonomi, Brilian International, 2010.

${ }^{23} \mathrm{Ibid}$ berjalan sehingga setiap orang bekerja untuk memenuhi kebutuhannya sendiri tanpa harus menggangu orang lain.

Dari ketiga kecendrungan tersebut, smith sangat menekankan kepada kecendrungan kepentingan diri sendiri. Smith meyakini bahwa pada dasarnya manusia bersifat serakah, manusia tidak pernah puas akan sesuatu dan tidak pernah secara ikhlas memberikan sesuatu kepada orang lain. Adam smith mengatakan, "it is not form the benevolence of the butcher, the brewer, or the baker, that we expect our dinner, but form their regard of their own interest". ${ }^{24}$ Dari pernyataan smith ini lahir ungkapan yang terkanal yaitu "there is no free lunch" tidak ada makan siang gratis". Ungkapan tersebut menjelaskan bagaimana kecendrungan manusia yang sangat kuat akan kepentingan dirinya. Dalam hal ini Smith mengatakan "we address ourselves not to their humanity but to their self - love, and never talk to them of our own necessities but of their adventages". ${ }^{25}$ Dalam pernyataan ini, adam smith sangat menekankan bahwa setiap orang cenderung tidak berbicara tentang sisi kemanusiaannya, tapi pada kecintaan mereka terhadap dirinya sendiri.

Cinta pada diri sendiri (self love) menjadi dasar tindakan manusia

${ }^{24}$ Adam Smith, The Wealth of Nation, Book I, chapter II.

${ }^{25}$ Ibid. 
memenuhi kebutuhannya. Namun, kecintaan ini tidak akan mengalami benturan dengan kepentingan orang lainnya. ${ }^{26}$ Karena menurut smith, dengan membiarkan cinta diri ini berjalan dengan sendirinya, maka setiap orang akan saling membutuhkan satu sama lain. Karena, sudah pasti setiap orang tidak mampu memenuhi semua kebutuhannya sendiri dia membutuhkan bantuan orang lain. Misalnya, seorang petani hanya mampu memenuhi kebutuhannya akan beras tapi tidak mampu memenuhi kebutuhannya akan pakaian, oleh karena itu dia membutuhkan tukang jahit untuk memenuhi kebutuhannya akan pakaian. Begitupun sebaliknya, tukang jahit hanya mampu memenuhi kebutuhannya akan pakaian tapi tidak mampu memenuhi kebutuhannya akan beras, maka dia membutuhkan petani untuk hal tersebut. Berangkat dari setiap kebutuhan individual tersebut, maka setiap orang akan saling bekerjasama dengan orang lain. Semakin banyak kebutuhan seseorang maka semakin besar ikatan sosial yang akan dia bangun dengan orang lain. Dalam hal ini smith mengatakan "every individual ... generally, indeed, neither intends to promote the public interest, nor knows how much he is promoting it. .. he intends

\footnotetext{
${ }^{26}$ W. I. M. Poli Tonggak - Tonggak Sejarah Pemikiran Ilmu ekonomi, Brilian International, 2010.
}

only his own gain, and he is in this, as many other cases, led by an invisible hand no promote an end which was no part of his intention". ${ }^{27}$ Dari penjelasan smith tersebut, kita memahami kapitalisme sangat menekankan kepada kepentingan individu, mereduksi kepentingan masyarakat dan sangat menentang bentuk campur tangan pemerintah dalam masalah ekonomi (laissez Freire, Laissez Passer) $^{28}$.

Usulan Smith untuk kebebasan individu kemudian memicu dan memberikan pembenaran atas terjadinya keserakahan ${ }^{29}$, kecurangan bahkan memicu pergolakan sosial, perusakan lingkungan, dan penyalahgunaan kekuasaan ${ }^{30}$. Berangkat dari pemikiran smith tersebut, kita dengan lumrah melihat seorang kapitalis yang serakah melakukanpenipuan, kecurangan, dan mengelabui konsumen, dan karenya mereka mengejar kepentingan diri sendiri dengan mengorbankan kepentingan publik.

\footnotetext{
${ }^{27}$ Adam Smith, The Wealth Of nation, Book IV, chapter II.

${ }^{28}$ Mark Skousen, Sang Maestro "Teori - Teori Ekonomi Modern": Sejarah Pemikiran Ekonomi, alih bahasa Tri Wibowo Budi Santoso, Prenada, 2006.

${ }^{29}$ Yaitu tindakan memiliki property secara berlebihan tidak berdasakran tujuan dari property tersebut. Lihat aristoteles dalam M Anton Athoillah \& Bambang Q Aness, Filsafat Ekonomi Islam, 2005

${ }^{30}$ Lux, 1990 dalam Mark Skousen, Sang Maestro "Teori-Teori Ekonomi Modern": Sejarah Pemikiran Ekonomi, alih bahasa Tri Wibowo Budi Santoso, Prenada, 2006.
} 
Berbeda dengan asumsi yang dibangun oleh kapitalisme tentang manusia. Islam tidak berangkat dari pemahaman dikatomis (logika oposisi biner) seperti kerangkan filsafat eropa. Logika oposisi biner sebagaimana yang dijelaskan diatas menempatkan segala sesuatu dalam posisi saling berhadap - hadapan dan tidak memiliki kaitan, misalnya jiwa dan badan, pluralitas dan kemajemukan, materi dan non materi, transendental dan imanen, milik saya dan milik orang lain. Logika semacam itu senantiasa menempatkan seseorang dalam posisi hitam putih, egoistic dan individualistik.

Dalam pandangan filsafat islam, sama seperti arsitoteles, tujuan akhir yang ingin dicapai manusia adalah kebahagiaan. Namun, kebahagiaan dalam perpesktif islam tidak terbatas pada kepemilikan property material sebagai sarana kebahagiaan, tetapi pada kebahagiaan yang akan dicapai di hari akhir. ${ }^{31}$

Ajaran islam berangkat dari fondasi kalimat tauhid, yaitu suatu kalimat yang dengan penuh kesadaran tunduk kepada suatu dzat yang maha agung yaitu Allah SWT. ketundukan kepadaAllahSWT tersebut didasarkan kepada keyakinan bahwa segala

${ }^{31}$ Mustamin Al Mandary, Jurnal Mulla Shadra, Volume 1, Nomor 3, 2010. sesuatu berasal dari Allah dan segala sesuatu akan kembali kepadanya ${ }^{32}$.

Berdasarkan ayat tersebut, Murthada Mutahhari menjelaskan bahwa dalam konsepsi Islam manusia bukan sekedar Homo economicus (manusia ekonomi) dalam tafsiran adam smith yang rakus dan egois. Manusia memiliki martabat dan kemuliaan. Allah SWT menjadikan manusia unggul atas banyak mahkluk lainnya, hal ini sangat bertentangan dengan pemikiran eropa dimana manusia tidak memiliki perbedaan essensial dengan mahluk lainnya. ${ }^{33}$ Dalam alquran surah al isra ; 70, Allah SWT berfirman "Dan Sesungguhnya telah kami muliakan anak - anak Adam. Kami angkut mereka di daratan dan dilautan. Kami beri mereka rezeki dari yang baik - baik. Dan kami lebihkan mereka dengan kelebihan yang sempurna atas kebanyakan mahkluk yang telah kami ciptakan". ${ }^{34}$

Namun, menurut Mutahhari manusia baru dapat merasakan bagaimana sesungguhnya dirinya itu kalau dia mewujudkan martabat dan kemuliaanya serta memandang dirinya tak pantas diperbudak dan tak

${ }^{32} \mathrm{Al}$ Quran dan Maknanya, Surah Albaqrah, jus 2 ayat 156. Terjemahan makna disusun oleh M Quraish Sihab.

${ }^{33}$ Murthada Mutahari, Man and Universe" dialih bahasakan oleh Ilyas Hasan, Manusia dan Alam Semesta: Konsepsi Islam Tentang Jagat Raya, Penerbit Lentera, 2002.

${ }^{34}$ Mushaf Al Quran, terbitan Lentera Hati, 2013. 
layak berbuat buruk. ${ }^{35}$ Dengan kata lain, islam mengakui bahwa dalam diri manusia terdapat potensi menjadi baik dan menjadi buruk, aktualnya kedua potensi tersebut sangat tergantung pada pola asuh, kualitas pendidikan, dan lingkungan dimana seseorang tumbuh. Akan tetapi, islam tidak memandang hal tersebut sebagaimana pandangan John Lukce, yang melihat manusia seperti kertas tabularasa yang kosong dari apapun. ${ }^{36}$

Meskipun sifat - sifat baik dan buruk bersifat potensi dalam diri manusia, namun Allah SWT memberikan kanal khusus agar manusia bisa megaktulkan potensi kemanusiaanya dan sekaligus menjadi penutup saluran potensi keburukannya. Allah SWT menyebut hal tersebut sebagai Fitra yaitu perjanjian antara Allah SWT dengan manusia ketika berada di alam rahim. Hal tersebut difirmankan oleh Allah SWT dalam AlQuran surah Al A'raf : 172 "Dan (ingatlah) ketika Tuhanmu mengeluarkan keturunan anak - anak Adam dari sulbi mereka dan Allah mengambil kesaksian terhadap jiwa mereka (seraya berfirman): "bukankah Aku ini Tuhanmu?" mereka menjawab: betul (Engkau Tuhan kami), kami

${ }^{35}$ Murthada Mutahari, Man and Universe" dialih bahasakan oleh Ilyas Hasan, Manusia dan Alam Semesta: Konsepsi Islam Tentang Jagat Raya, Penerbit Lentera, 2002

${ }^{36} \mathrm{~F}$ Budi Hardiman, Pemikiran-Pemikiran yang Membentuk Dunia Modern, Penerbit Erlangaa, 2011 menjadi saksi" serta dalam surah Ar Rum : 30 "Maka Hadapkanlah Wajahmu dengan Lurus kepada Agama (Allah). (tetaplah atas) fitrah Allah yang telah menciptakan manusia menurut fitrah itu. ${ }^{\text {"37 }}$

Murthada mutahhari menafsirkan fitrah tersebut sebagai suara ilahiah yang ditempatkan dalam hati setiap manusia yang senantiasa memberikan bisikan kepada manusia akan keberadaan Allah SWT dan kecintaan terhadap kebenaran, keadilan dan rasa kemanusiaan lainnya. ${ }^{38}$ Fitra tersebut menjadi wawasan moral sehingga manusia dapat mengetahui mana yang baik dan mana yang buruk dengan menggunakan ilham alamiahnya. Hal ini diperkuat oleh Firman Allah SWT dalam surah Asy Syams : 7-8) "Demi jiwa serta penyempurnaanya. Maka Allah mengilhamkan kepada jiwa itu (jalan) kefasikan dan ketakwaannya. ${ }^{39}$

SifatrakusyangolehAdamSmith sebagaifaktor utamayang mendorong seseorang dalam bekerja, juga diakui oleh islam. Namun, berbeda dengan smith, islam menempatkan sifat rakus manusia sebagai faktor utama timbulnya kejahatan jika

${ }^{37}$ Mushaf Al Aquran, cetakan penerbit lentera hati, 2013.

${ }^{38}$ Murthada Mutahari, Man and Universe" dialih bahasakan oleh Ilyas Hasan, Manusia dan Alam Semesta: Konsepsi Islam Tentang Jagat Raya, Penerbit Lentera, 2002

${ }^{39}$ Mushaf Al Aquran, cetakan penerbit lentera hati, 2013. 
tidak dikendalikan. Hasrat manusia tidak memiliki ujung namun bisa dikendalikan dengan mengingat Allah SWT ${ }^{40}$. dalam alquran surah $\mathrm{Ar}$ Rad : 28 "hanya dengan mengingat Allah sajalah hati menjadi tentram"41.

penjelasan mengenai asumsi/ konsep tentang manusia, baik yang dikemukakanoleh Kapitalisme(Adam Smith) maupun Islam (Murthada Mutahari) memberikan pandangan yang utuh mengenai perbedaan yang sangat kontradiktif tentang manusia. Meskipun kedua pandangan tersebut bertujuan untuk memberikan jalan bagi kebahagiaan manusia. Tetapi, perbedaan konsep desar tentu akan memberikan akibat yang berbeda.

\section{Konsep Hak Milik.}

Sebagaimana yang dijelaskan pada bab pendahuluan. Konsep hak milik adalah fondasi dari bangunan ekonomi dan implikasi dari konsep hak milik tersebut berkaitan dengan kesejahtraan dan kebahagiaan manusia. Akan tetapi, dikarenakan asumsi yang tidak tepat mengenai manusia dan kebutuhan manusia, maka sistem ekonomi yang dibangun justru menciptkan ketidak adilan sosial, dimana terajadi jurang yang sangat lebar antara kelompkok kaya

${ }^{40}$ Murthada Mutahari, Man and Universe" dialih bahasakan oleh Ilyas Hasan, Manusia dan Alam Semesta: Konsepsi Islam Tentang Jagat Raya, Penerbit Lentera, 2002

${ }^{41}$ Mushaf Al Aquran, cetakan penerbit lentera hati, 2013 dan kelompok miskin. Oleh karena itu, kajian tentang konsep hak milik dalam perspektif sistem ekonomi kapitalis perlu dilakukan kajian dan dekonstuksi untuk membangun suatu sistem yang lebih memberikan keadilan sosial bagi manusia.

Kapitalisme sebagaimana yang dijelaskan sebelumnya sangat menekankan kepada kebebasan individu dan kepentingan individu. Oleh karena itu, konsep kepemilikan berangkat dari kepemilikan seseorang atas dirinya sendiri. Setiap orang secara bebas dan merdeka memiliki dirinya dan setiap hal yang terkait dengan dirinya. Dengan kata lain, setiap orang dapat memiliki apapun yang sesuai dengan dirinya.

Dalam sistem kapitalisme, jika orang memiliki sesuatu maka orang tersebut berhal untuk melakukan apa saja terhadap sesuatu tersebut, kalau seseorangmemiliki rumah atau tanah, maka orang tersebut bisa menjual, menempati, ataupun membiarkan rumah/ranah tersebut kosong selama bertahun - tahun lamanya. Dalam konsep ini pula setiap orang bisa memiliki apapun dalam jumlah tidak terbatas. Kapitalisme yang berangkat dari motif kepentingan diri tidak menghendaki ada peraturan yang berlebihan atau pembatasan mengenai hak milik. ${ }^{42}$

${ }^{42}$ Save M Dagun Pengantar filsafat ekonomi, Penerbit Rineka Cipta, 1992 
Sistem ini dengan sendirinya melahirkan kesenjangan sosial akibat distribusi sumber daya yang tidak adil. Seseorang yang memiliki kekuatan (jabatan) akan dengan mudah memiliki banyak property dikarenakan kekuasaanya tersebut dibandingkan dengan masyarakat biasa yang tidak memiliki kekuatan apapun. Begitupun dengan seseorang yang memiliki capital yang besar akan dengan mudah memenagkan persaingan pasar bahkan mampu memonopoli pasar dengan mencegah produsen lain untuk memasuki pasar tersebut.

Kepemilikan terhadap property yang bersifat mutlak juga memiliki implikasi terhadap lahirnya berbagai persoalan sosial. Di negara - negara berkembang khususnya di Indonesia, persoalan kepemilikan mutlak ini banyak dijumpai khususnya dalam kasus penggusuran terhadap masyarakat miskin. Seseorang yang memiliki capital dalam jumlah banyak serta akses kepada kekuasaan yang kuat mampu memiliki sejumlah tanah di daerah tertentu, kemudian setelah bertahun - tahun kemudian daerah tersebut berkembang dan tanahnya tersebut memiliki nilai jual yang tinggi, orang tersebut baru kemudian mau mengelolah tanahnya tersebut. Masalah terjadi ketika di atas tanah tersebut telah ada pemukiman masyarakat miskin khususnya masyarakat pendatang yang menampati tanah tersebut dikarenakan tanah tersebut adalah tanah kosong. Maka yang terjadi adalah penggusuran. Tentu kita tidak bisa menyalahkan pengadilan dikarenakan tanah tersebut memeng bukan tanah milik kelompok miskin, tapi tanah milik seorang pengusaha atau tuan tanah yang selama bertahun - tahun entah kemana dan tiba - tiba saja munculmembawa bukti sertifakat kepemilikan atas tanah tersebut.

Disini yang salah adalah sistemnya, sistem yang menjamin seseorang dapat memiliki suatu property secara mutlak dan dapat melakukan apa saja terhadap property tersebut meskipun property tersebut hanya dibiarkan begitu saja, tidak ditempati atau tidak dimanfaatkan untuk kepentingan ekonomi. Sistem ini menciptkan kelas dimana hanya sekolompok kecil orang menguasai sebagian besar tanah di suatu wilayah. Bukan hanya itu, di kota kota besar seperti Jakarta, Surabaya, bali dan Makassar, isu reklamasi telah memicu perdebatan yang alot antara pengusaha dan penguasa dengan aktifis lingkungan dan hak asasi manusia. Secara manusiawi, aktifitas reklamasi sangat merugikan kelompok nelayan dan masyarakat yang hidup di pesesir dan sangat menguntungkan pengusaha khususnya developer. Bagaimana tidak, dengan hanya bermodalkan timbunan tanah yang harganya 
murah, dia dapat menjadikan pantai sebagai tanah dengan nilai milyaran. Sementara itu, kelompok nelayan khususnya nelayan dengan perahu kecil kehilangan mata pencaharian tunggal mereka dan terpaksa beralih profesi menjadi tukang batu, tukang becak, kuli bangunan dan lain - lain. Akan tetapi secara hokum, reklamasi adalah sesuatu yang legal, tidak dilarang dan kepemilikannya dijamin oleh hokum. Inilah anomaly dalam sistem hak milik berbasis kapitalisme yang sangat memuju kerakusan manusia sebagai faktor utama yang menggerakaan roda perekonomian.

Beberapa abad yang lalu, seorang filosof dan ekonom yang bernama Karl Marx telah menyadari akan bahaya dari sistem kapitalisme akibat dari asumsi - asumsi yang dibangunnya. Marx memberikan penafsiran sendiri mengenai konsep hak milik. Menurut marx, konsep hak milik saya dan milik anda (orang lain) tidak berarti menjurus ke pengertian milik dari saya atau milik dari anda. Marx mengajukan hipotesa mengenai hak milik yang tidak permanen. Marx menajukan hipotesea mengenai milik bersama. ${ }^{43}$ Namun, hipotesis milik bersama yang diajukan marx dalam perjalannya terbukti lebih keliru dari pada teori milik yang diajukan oleh smith (kapitalisme). Oleh karena karena itu, dalam artikel ini tidak akan

${ }^{43}$ Save M Dagun Pengantar filsafat ekonomi, Penerbit Rineka Cipta, 1992 diulas lebih mendalam mengenai padangan karl marx, mengingat kejatuhan teori tersebut beberapa decade yang lalu.

Konsep hak milik dalam islam berangkat dari keyakinan terhadap Allah SWT sebagai penguasa mutlak alam dan seluruh isinya. Setiap orang islam meyakini bahwa apa yang dimilikinya saat ini termasuk dirinya sendiri hanyalah titipan dari Allah SWT dan pada suatu saat nanti, akan kembali kepada Allah SWT. diri (badan) dan harta benda yang dimiliki hanyalah sarana untuk beribadah kepada Allah SWT.

Setiap manusia - terutama dalam kapasitasanya sebagai pribadi - memiliki berbagai kebutuhan, keinginan dan hasrat yang harus dipenuhi. Olehnya itu, islam telah memfasilitasi para individu untuk memenuhi berbagai kebutuhan mereka mealalui institusi kepemilikan pribdadi, yang mana islam telah membangun dan memformulasikan berbagai dasar dan syaratnya. ${ }^{44}$

Ketika hubungan diantara manusia terjalin dan kemudian masyarakat terwujud, maka akan muncul berbagai kebutuhan umum masyarakat. Islam telah menjalin pemenuhan berbagai kebutuhan dan keinginan masyarakat melalui

${ }^{44}$ Muhammad Baqir Sadr Iqtishaduna, Penerbit Zahra Publishing House, 2008. alih bahasa oleh Yudi. 
institusi kepemilikan bersama atas sumber - sumber produksi tertentu. ${ }^{45}$

Oleh karena diantara kelompok masyarakatadabeberapaindividuyang tidak mampu memenuhi kebutuhan pribadinya dikarekanakan beberapa faktor seperti sakit, cacat, tertimpa musibah (bencana) atau faktor lainnya, maka individu tersebut akan tertekan karena tidak bisa memenuhi kebutuhan pribadinya, akibatnya keseimbangan sosial akan terganggu. Dalam kasus ini islam memunculkan bentuk ketiga dari kepemilikan yaitu kepemilikan negara sehingga dengan hal itu, kepala negara bisa menjaga keseimbangan sosial. ${ }^{46}$

Dari penjelasan tersebut, dapat dipahami bahwa islam mengakui dan menekankan kepada tiga bentuk kepemilikan, yaitu kepemilikan pribadi, kepemilikan bersama dan kepemilikan negara. Tidak seperti kapitalisme yang menolak campur tanganya dalam proses kepemilikan, islam justru mengharuskan adanya negara dengan tujuan untuk menjada keseimbangan sosial.

Untuk menciptakan proses kepemilikan yang adil maka islam juga mengatur mengenai proses kepemilikan dalam bentuk distribusi. Dalam kapitalisme distribusi dibatasi pada distribusi pendapatan. Yaitu konsep yang melihat kesejahtraan individu dapat ditingkatkan dengan mendistribusi pendapatan kepada setiap orang. Namun, prinsip ini justru mempertahankan ketimpangan sosial dikarenakan distibusi pendapatan hanyalah ujung dari proses ekonomi yang bersumber dari sumber produksi.

Dalampandaganislam, distribusi harus dimulai dari distribusi sumber - sumber produksi yaitu distribusi kepemilikan tanah, bahan tambang, mineral, dan mesin. Distribusi yang tidak adil dalam sumber - sumber produksi ini akan menciptakan ketimpangan. Misalnya dalam kasus kepemilikan tanah, distribusi kepemilikan tanah yang tidak adil dan hanya dikuasai oleh segelintir orang akan menyebabkan banyaknya penggusuran dan kemiskinan.

Oleh karena itu, dalam islam kepemilikan atas tanah dan sumber - sumber produksi lainnya dimiliki oleh Allah SWT dan dikelola oleh negera. Individu bisa memiliki tanah tapi tidak dalam bentuk kepemilikan mutlak. Tapi kepemilikan atas tanah tergantung pada pemanfaatn tanah tersebut. Sebidang tanah milik seseorang dalam jangka waktu yang lama tidak terkelola maka negara dapat mengambil tanah tersebut dan memberikan kepada orang yang membutuhkan dan bisa mengelola tanah tersebut. Dengan prinsip ini maka, setiap orang dapat memiliki tanah untuk dirinya dan kelurganya 
dan memanfaatkan untuk memenuhi kebutuhan dirinya dan keluarganya. Dengan prinsip ini pula kita tidak akan lagi menjumpai kepemilikan tanah yang terkonsentrasi hanya kepada beberapa orang saja.

\section{Kesimpulan dan saran}

\section{Kesimpulan}

Sistem ekonomi kapitalisme yang dibangun diatas asumsi terhadap manusia yang keliru menyebabkan terjadinya ketidak seimbangan sosial dan ketimpangan sosial dalam bentuk ketimpangan kepemilikan. Dalam kapitalisme kita menjumpai realitas dimana segilinti orang menguasai begitu banyak properti/tanah, sementara sekelompok masayarakat hidup diatas tanah orang lain dan sewaktu - waktu dapat digusur oleh pemiliknya.

\section{Ketimpangan}

dan ketidakseimbangan sosial tersebut dapat direduksi dengan menerapkan sistem ekonomi yang dibangun diatas asumsi yang benar mengenai manusia. Kenapa harus seperti itu, karena manusia merupakan subjek sekaligus objek ekonomi. Manusia adalah pelaku dari ekonomi sekaligus pengguna dari ekonomi. Sehingga harus dibangun suatu sistem yang dapat membuat setiap orang bisa memenuhi kebutuhannya sendiri. Sistem seperti itu hanya dapat dibangun dengan menerapkan asumsi yang betul - betul sesuai dengan hakekat manusia.

Asumsi tersebut dapat dijumpai dalam ajaran islam. Islam menempatkan manusia sebagai makhluk yang paling sempurna di dunia. Meskipun manusia memiliki potensi baik dan buruk. Namun Allah SWT secara khusus menyediakan kanal yang dapat mengarahkan manusia untuk mengaktulkan potensi baiknya. Islam memandang bahwa konsep hak milik memeng tidak dapat dipisahkan dari manusia. Namun, hak milik tidak terbatas pada kepemilikan individu seperti kapitalisme. Islam membagi kepemilikan ke dalam tiga jenjang. Jenjang pertama adalah kepemilikan pribadi, kepemilikan pribadi diciptakan dikarenakan secara individu manusia memeng membutuhkan sesuatu secara pdibadi untuk menopang kehidupannya. Kemudian kepemilikan bersama, adalah kepemilikan yang diakibatkan lahirnya masyarakat sehingga tercipta pula kebutuhan bersama. Misalnya kebutuhan akan tempat ibdah, kebutuhan akan sarana olahraga dan berbagai sarana umum lainnya. Kemudian bentuk kepemilikan terakhir adalah kepemilikah negara. Kepemilikan negara ini tidak bersifat mutlak seperti sosialisme komunis. Namun bersifat penyeimbang dalam kehidupan sosial. Kepemilikan negara bertujuan untuk menciptakan 
keadilan sosial dan kesejahtraan untuk semua orang.

\section{Saran}

Penelitian ini masih memiliki banyak kelemahan, diantaranya kekurangan refrensi, ketidak mendalaman kajian. Oleh Karena itu, penulis menyaraknkan kepada pembacajikainginmengkajimengenai topic ini agar lebih memperdalam kajiannya sehingga tema ini betul betul bisa bermandaat di kehidupanya nyata masyarakat.

\section{DAFTAR PUSTAKA}

Al-Qur'an al- Karim.

Abdul Ghafur, Ruslan Noor. Kebijakan Distribusi Ekonomi Islam Dalam Membangun Keadilan Ekonomi Indonesia, ISLAMICA 6, no. 2 (2012), h. 316-327.

-------,Konsep Distribusi dalam ekonomi Islam, Cet I; Yogyakarta:Pustaka Pelajar,2013

Afzalurrahman, Doktrin Ekonomi Islam , Cet II; Yogyakarta: PT Dana Bakti

Ali, Mabid,dkk. Redistributive Justice in a Developed Economy: An Islamic Perspective, paper presented at $6^{\text {th }}$ International Conference on Islamic Economics and Finance, (Jakarta: Bank Indonesia, 2005Wakaf, 1996.

Amir,Yasraf Piliang, Dunia Yang Dilipat: Tamasya Melampui Batas
- Batas Kebudayaan, Edisi ke tiga, Penerbit Matahari, 2011.

-, Posrealitas: realitas Kebudayaan dalam era posmetafisika, Penerbit Jalasutra, 2009.

Athoillah, M. Anton dan Bambang Q Annes. Filsafat ekonomi islam, Bandung: Sahifa, 2013.

Azwar, Adiwarman karim. Sejarah pemikiran ekonomi islam, Cet. III; Jakarta: Rajawali press, 2012.

Budi, F, Hardiman, Pemikiran Pemikiran yang Membentuk Dunia Modern, Penerbit Erlangaa, 2011 Chaudry,Muhammad Syarif, "Fundamental of Islamic Economic" terj. Suherman, Sistem Ekonomi Islam: Prinsip Dasar, Cet I. Jakarta: Kencana, 2006.

Clement,,Kevin.P, Teori Pembangunan dari kiri ke kanan, Cet. II; Yogyakarta: Pustaka Pelajar offset, 1999.

Conte,Christopher, Ekonomi Amerika Serikat. Cet. I; Departemen Luar negeri Amerika Serikat, 2013.

Dakake, Maria Massi. The Charismatic Community: Sh'iteIdentitiyInEarly Islam. Cet I;New York University of New York Press,2007.

Departemen Agama Republik Indonesia, Mushaf Alqur'an dan Terjemah, Cet. I; Jakarta: AlHuda, 2002.

Chapra, Umer, Masa depan Ilmu Ekonomi: sebuah tinjauan Islam, 
Cet. I; Jakarta: Gema Insani, 2001.

Hamid, Arfin . Membumikan ekonomi syariah di indonesia, Cet. I, Jakarta: ELSAS, 2007.

Kaelan M.S., Metode Penelitian agama kualitatif Interdisipliner, Yogyakarta; Paradigma,2010.

Khaldun , Ibn, Muqaddimah, terj. Ahmadie, Muqaddimah Ibn Khaldun, Jakarta: Pustaka Pelajar, 2006.

Khan,Moh Lateef Economic Tought of Muhammad Baqir al Sadr : Study of Iqtishaduna (our Economics), Dissertation: University of Kashmir, 2011.

M. Anthon Athoillah ,dkk. Filsafat Ekonomi Islam,Cet I, Jakarta;Sahifa. 2013

M.dagun, Save . Pengantar filsafat Ekonomi, Cet. I; Jakarta : PT Rineka Cipta ,1992.

Mubyarto, Membangun SistemEkonomi, BPFE Yogyakarta, 2000

Mujahidin,Akhmad.dkk. Ekonomi Islam: Sejarah, Konsep, Instrumen, Negara dan Pasar,Cet II. Jakarta: Raja Grafindo, 2013.

Mustafa Edwin Nasution, Pengenalan Eksklusif Ekonomi Islam, Cet I. Jakarta: Kencana, 2006.

Mustamin Al Mandary, Jurnal Mulla Shadra, Volume 1, Nomor 3, 2010.
Muthahhari, Murthada, Masyarakat dan sejarah, Cet VI; Bandung: Mizan, 1998.

--------, Man and Universe" dialih bahasakan oleh Ilyas Hasan, Manusia dan Alam Semesta: Konsepsi Islam Tentang Jagat Raya, Penerbit Lentera, 2002

Nata, Abuddin. Metodologi studi Islam, Cet. III; Jakarta: Raja Grafindo Persada, 1999.

P. Sumadji,dkk. Kamus Istilah Ekonomi, Cet. I; Gama Press, 2006.

Poli,W.I.M, Tonggak-Tonggak Sejarah Pemikiran Ekonomi, Cet. I; Sidoarjo: Brilliant International, 2010 .

Pusat pengkajian dan pengembangan ekonomi Islam, Ekonomi Islam. cet.III; Jakarta: Rajawali press, 2011

Rakhmat, Jalaluddin, Catatan Kang Jalal, Cet. II; Bandung: Remaja Rosdakarya offset, 1999.

-------, Islam Aktual, Cet IV; Bandung: Mizan, 1992.

Ritzer,George,dkk. Teori Sosiologi Modern, Cet VI; Jakarta; Kencana, 2004.

Rivai, veitzhal dan Andi Buchari. Islamic Economic, Jakarta: Bumi Aksara, 2009.

Rosyidi, Pemikiran Islam Kontemporer - Analisis Komparatif Terpilih, Jakarta: Rajawali Press, 2010. 
Russel, Betrand“sejarah Filsafat Barat dan impilikasinya terhadap kondisi sosial politik masa kini

Sadr, Muhammad Baqir. Al-Madrasah al-Islamiah, terj. Muslim Arbi, Islam dan Mazhab Ekonomi, Jakarta: YAPI, 1989.

-----, Muhammad Baqir. Iqtishaduna , terj. Yudi, Buku Induk Ekonomi Islam, Jakarta: Zahra, 2008.

-----, MuhammadBaqir.Iqtish $a<$ duna $<$ , Cet. II; Iraq .1987.

Sen, Amartya "On Economic Inequality"dalam Muhammad sholihin, eds., Pengantar Metodologi Ekonomi Islam. Cet. I; Yogyakarta: Ombak, 2013.

Shihab, M. Quraish. Tafsir al Misbah, Cet. V; Jakarta: Lentera Hati, 2012.Sholihin, Muhammad Pengantar Metodologi Ekonomi Islam, Cet. I; Yogyakarta: Ombak, 2013.
Smith, Adam "An Iquiry Into the Nature and Causes of the Wealth of Nations, Cet.4.1965. diakses 4 maret 2014.

Skousen Mark. The Making of Modern Economics; The Lives and Ideas of The Great Thinkers, terj. Tri Wibowo Budi Santoso, Sang Maestro; Teori- Teori Ekonomi modern, Jakarta: Prenada, 2006.

Suriasumantri, Jujun Filsafat Ilmu Pengetahuan sebuah pengantar Populer, Penerbit Pustaka Sinar Harapan, 2007.

Suryajaya, Martin, Asal Usul Kekayaan,Cet I;Yogyakarta; Resist Book, 2013.

Syihabuddin, Atok. "Distribusi Kekayaan (Study Komparatif pemikiran Baqir Sadr dan Taqiy al din al Nabaniy), Tesis. Surabaya: Institut Agama Islam Negeri Sunan Ampel Surabaya, 2011

T.M. Soerjanto Poespowardojo \& Alexander Seran, Filsafat Ilmu Pengetahuan, Penerbit Kompas, 2015. 